\title{
The Gender Gap: Past, Present and Perspectives
}

Frank ELBERS ${ }^{1}$

Ana-Maria GRIGORE ${ }^{2}$

\begin{abstract}
Nowadays in most industrialised countries women outperform men at all education levels but in the workplace they are under-paid and under-promoted. At the same time there is broad global consensus that gender equality is a fundamental human right and, in fact, is linked to a country's overall economic performance. Although in Romania the status of women has improved considerably in recent years, differences between women and men in economic participation still persist.

The aim of this paper is to answer the question: where do we stand today with regard to the gender gap in the economy? The research is based on official reports on gender inequality, data collected by the European Union, United Nations and World Economic Forum, legislation in force, and the most important and relevant studies in the literature, which all point to a continued gender gap in Romanian society.
\end{abstract} gender parity

JEL classification: J16, E70

DOI: $10.24818 / \mathrm{RMCI} .2018 .5 .504$

\section{Introduction}

Gender is an important marker of social and economic stratification, and hence of exclusion. (Seguino, 2016) Despite a global consensus that gender equality matters (United Nations, 1995), policy makers continue to wrestle with the question why stark gender gaps persist. (England et al, 1988; Magnusson, 2010; Cerise \& Francavilla, 2012; Bohnet, 2016; Schuller, 2018)

Women can be critical for innovation and long-term growth. Organisations where women hold $30 \%$ of leadership positions could add up to $6 \%$ to their net margins, according to recent research. (Noland et al, 2016; Brooke-Marciniak, 2018; see also Woetzel et al, 2015) Yet women still face an uphill battle in leadership positions. The higher women climb, the more biases, challenges and stereotypes they face. (Brooke-Marciniak, 2018).

As far as Romania is concerned, an important step in reducing gender inequality was the accession to the European Union. Although the principle of

${ }^{1}$ Frank Elbers, independent researcher, E-mail: frank.elbers@mail.utoronto.ca.

${ }^{2}$ Ana-Maria Grigore, University of Bucharest, E-mail: ana.grigore@faa.unibuc.ro. 
equality is legally enshrined (Law 232/2018 amending and supplementing Law No. 202 of 2002 on equal opportunities and treatment of women and men) it is not fully respected. (Vaileanu et al, 2008; Tudorache, 2011) In the above-mentioned studies the causes that lead to the perpetuation of gender inequality include stereotypes, mentalities, culture, religion, language and education.

One other cause of the gender gap, which we will not address in this paper, is the fact that women in countries around the world take responsibility for the bulk of unpaid work, like caring for children and elderly, and household tasks, as underlined Katrine Marçal's, Who Cooked Adam Smith's Dinner? A Story About Women and Economics. Marçal reminds us of the old joke among economists: "[I]f a man marries his housekeeper, the GDP of the country declines. If, on the other hand, he sends his mother to an old-age home, it increases again. In addition to the joke saying a lot about gender roles among economists, it also shows how the same kind of work can be counted or not counted as part of the GDP ... If you want the full picture of the economy you can't ignore what half of the population is doing half of the time." (Marçal, 2015: 60)

The remainder of this paper is organised as follows. In the second section ("Conceptualisation and measurement") we introduce definitions of the gender gap, gender pay gap, gender parity and other concepts relevant to gender equality in the economy and how they can be measured. The third section ("Findings") we will review gender gaps indices and how Romania ranks compared to other EU member states. In the fourth section ("Underlying causes") we will drill deeper to explain the underlying factors in the variations in the gender participation, remuneration and advancement gaps and what causes them. The fifth and final section ("Perspectives") examines future perspectives and possible policy solutions to closing the gender gap.

\section{Conceptualisation and measurement}

Gender inequality, resulting in gender gaps, is not a new phenomenon. It has instead been a characteristic of societies for millennia, although to varying degrees across countries and over time. The emergence of the human rights agenda in the mid-20th century and women's movements across the world since the 1960s have contributed to increased global attention to this form of inequality. (Fraser, 1999; Bunch, 2012; Seguino, 2016) Increased participation of women in the workforce in industrialised nations as of the 1960s contributed to awareness of unequal gender relations in the economy as well. (Marçal, 2015) Gender equality assumes that all human beings, both men and women, are free to develop their personal abilities and make choices without the limitations set by stereotypes, rigid gender roles, or prejudices. Gender equality also means that different behaviours, aspirations and needs of women and men are considered, valued and favoured equally. It does not mean that women and men have to become the same, but that their rights, responsibilities and opportunities will not depend on whether they are born male or female. (UN-INSTRAW, 2011) In this context gender parity refers to 
contexts and situations in which an equal number of men and women hold positions in the private and public sector, for example on executive boards or seats in parliament. We speak of a glass ceiling if an unacknowledged barrier to advancement in a profession exists.

Gender refers to the array of socially constructed roles and relationships, personality traits, attitudes, behaviours, values, relative power and influence that society ascribes to the two sexes on a differential basis. Whereas biological sex is determined by genetic and anatomical characteristics, gender is an acquired identity that is learned, changes over time, and varies widely within and across cultures. Gender is relational and refers not simply to women or men but to the relationship between them. (UN-INSTRAW, 2011) The unequal relationship between men and women often results in gender gaps. The three gender gaps that we will address in this paper are the participation gap, the remuneration gap, and the advancement gap.

There are various institutions that have measured, monitored and diagnosed gender gaps over the past decades, including the Organisation for Economic Cooperation and Development (OECD), International Labour Organization (ILO), the World Economic Forum (WEF), and more recently, the newly established European Institute for Gender Equality (EIGE). The OECD has been collecting statistics since 1970 about the gender wage gap, defined as the difference between median earnings of men and women relative to median earnings of men (data refer to full-time employees and to self-employed). (OECD, 2018).

EIGE's Gender Equality Index measures gender gaps between women and men. It considers gaps that are to the detriment of either women or men as being equally problematic. Using 31 indicators the Gender Equality Index assigns scores for EU member states between 1 for total inequality and 100 for full equality in six core domains (work, money, knowledge, time, power and health). Indicators related to work and money are: FTE employment rate (\%); duration of working life (years); employed people in education, human health and social work activities (\%); ability to take one hour or two off during working hours to take care of personal or family matters (\%); Career Prospects Index (points, 0-100); mean monthly earnings (PPS); mean equivalised net income (PPS); not at-risk-of-poverty (\%); income distribution S20/S80 (\%). Data are available for 2005, 2010, 2012 and 2015.

The ILO's ILOSTAT (https://www.ilo.org/ilostat/) is the world's leading source of labour statistics. The ILO provides many of the statistics used by gender gap indices produced by EIGE, OECD and the World Economic Forum, yet does not publish a gender report itself, with the exception of Breaking through the Glass Ceiling: Women in Management (Wirth, 2004).

The WEF started publishing the Global Gender Gap Report in 2006 (Hausmann et al, 2006; Lopez-Claros \& Zahidi, 2005). The methodology has remained stable since its original conception, providing a basis for robust crosscountry and time-series analysis. There are three basic concepts underlying the Global Gender Gap Index, forming the basis of how indicators were chosen, how 
the data is treated, and how the scale can be used. First, the Index focuses on measuring gaps rather than levels. Second, it captures gaps in outcome variables rather than gaps in input variables. Third, it ranks countries according to gender equality rather than women's empowerment. These three concepts are briefly outlined below. (World Economic Forum, 2018) The Global Gender Gap Index is based on four sub-indices: Economic Participation and Opportunity; Educational Attainment; Health and Survival; and Political Empowerment. The Economic Participation and Opportunity sub-index is measured by the difference between women and men in labour force participation rates ("participation gap"); ratio of estimated female-to-male earned income and wage equality for similar work ("remuneration gap"); and the ratio of women to men among legislators, senior officials and managers, and the ratio of women to men among technical and professional workers ("advancement gap"). For an overview of indicators and sources underlying the Global Gender Gap Index, see World Economic Forum, 2018: 5 .

\section{Findings}

'We did it'! read the cover of the new year's issue of The Economist magazine in 2010. Women had overtaken men and now made up the majority of all university graduates in the OECD, the club of the 35 richest countries in the world. (Marçal, 2015: 56) Yet despite this closing of what we can call the competence gap, women are still far behind to close the gap in participation in the workforce (participation gap), equal pay for equal work (remuneration gap) and representation in higher management and leadership positions (advancement gap).

The world has collectively closed $68 \%$ of the overall gender gap. Stagnation in the proportion of women in the workplace and women's declining representation in politics, coupled with greater inequality in accessing health and education, offset improvements in wage equality and the number of women in professional positions, leaving the global gender gap only slightly reduced in 2018 compared to 2017. At the current pace, the data suggest it will take 108 years to close the overall, global gender gap.

According to the Global Gender Gap Report 2018 (World Economic Forum, 2018), the gender gap in Romania continues to close. Romania has closed the overall gender gap to slightly more than $71 \%$, which places Romania $63^{\text {rd }}$ in the global ranking, just behind Croatia (59), Kazakhstan (60) and Bosnia and Herzegovina (62) but quite far behind our neighbours Bulgaria (18), Moldova (35) and Serbia (38). 


\begin{tabular}{|c|c|}
\hline & \\
\hline 1. Iceland & 0.858 \\
\hline 2. Norway & 0.835 \\
\hline 3. Sweden & 0.822 \\
\hline 4. Finland & 0.821 \\
\hline 5. Nicaragua & 0.809 \\
\hline 6. Rwanda & 0.804 \\
\hline 7. New Zealand & 0.801 \\
\hline 8. Philippines & 0.799 \\
\hline 9. Ireland & 0.796 \\
\hline 10. Namibia & 0.789 \\
\hline
\end{tabular}

Figure 1. The Ten Highest Ranked Countries in the Global Gender Index (Source: World Economic Forum, 2018)

Romania scores very high when it comes to gender parity in education and health (like many other countries). There is almost no gap between women's and men's current access to primary-, secondary- and tertiary-level education and levels of female and male literacy are almost similar. Health and survival is based on scores for sex ratio at birth, which aims specifically to capture the phenomenon of "missing women", and women's and men's healthy life expectancy. This measure provides an estimate of the number of years that women and men can expect to live in good health by taking into account the years lost to violence, disease, malnutrition and other relevant factors. Romania ranks number 1, out of a total of 149 countries, on this sub-index, along with many other countries.

Romania ranks 79th on the political empowerment sub-index, measured as the gap between men and women at the highest level of political decision-making through the ratio of women to men in ministerial positions, the ratio of women to men in parliamentary positions, plus the ratio of women to men in terms of years in executive office (prime minister or president).

Of the four pillars measured, only one-economic opportunity-narrowed this year. This is largely due to a smaller income gap between men and women. At the same time, data suggest that proportionately fewer women than men are participating in the workforce. There are a number of potential reasons for this. One is that automation is having a disproportionate impact on roles traditionally performed by women. At the same time, women are under-represented in growing areas of employment that require STEM (science, technology, engineering and mathematics) skills and knowledge. Another potential reason is that the 
infrastructure needed to help women enter or re-enter the workforce - such as childcare and eldercare - is under-developed and unpaid work remains primarily the responsibility of women.

The other three pillars - education, health, and politics - saw a widening of the gender gap in 2018. In terms of political empowerment, the year-on-year deterioration can be partly attributed to women's small presence in head-of-state roles around the world. The data also suggest that a regional divergence is taking place on this issue, with 22 Western economies witnessing an improvement in political empowerment for women, while the gap widens in the rest of the world.

With an average remaining gap of $29.3 \%$, countries in Eastern Europe and Central Asia, including Romania, rank fourth globally, slightly behind Latin America and the Caribbean and about 5\% below Western Europe's regional average. Overall, the performance of countries across the region is somewhat less divergent than in other parts of the globe. The gap between the top-ranked regional countries, Slovenia (11th), Latvia (17th), and Bulgaria (18th) - which score in the top 20 of the overall Index and have closed $78 \%, 76 \%$ and $76 \%$ of their overall gender gap, respectively - and the lowest-ranked countries, Romania, Georgia, Hungary, and Tajikistan-which have closed $71 \%, 68 \%, 67 \%$ and $64 \%$ of their overall gender gap, respectively - is within a range of no more than $10 \%$. With an average remaining gap of $29.3 \%$, it will take Eastern Europe and Central Asia 153 years to achieve total gender parity.

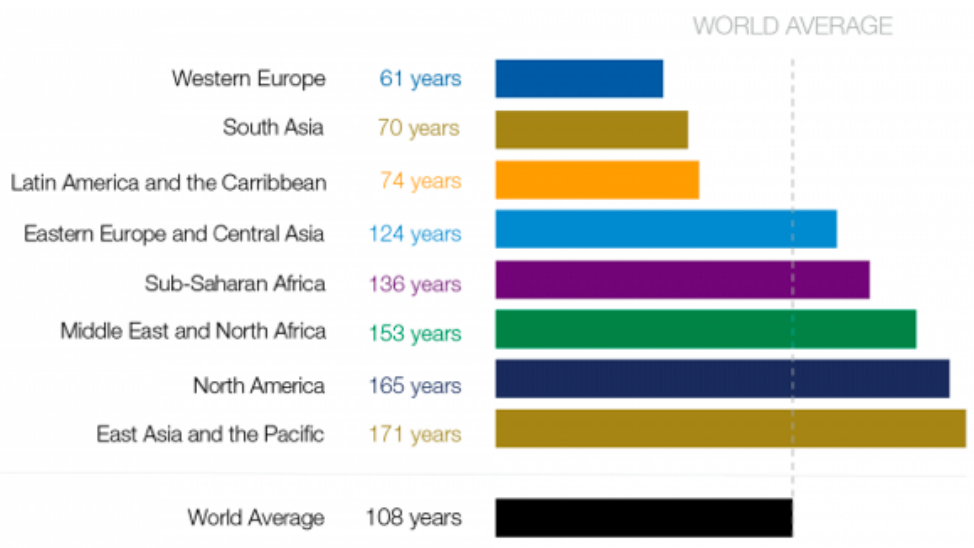

Figure 2. When are Regions Likely to Close the Gender Gap

(Source: World Economic Forum, 2018)

Women have caught up with men in terms of education. Women now actually surpass men in educational achievement. Although, according to INS statistics, women in Romania have a slightly higher level of education than men (about 2-3\% of women in addition to men who have tertiary education - i.e. faculty and over), the share of those with higher education is also in the less paid areas, 
such as education, while men migrate to more technologically and better paid sectors. (INS, 2018)

Remarkably, Romania is the EU member state in which the gender pay gap is the lowest (5.2\%), while the European average has stabilised for 16 years (see Figure 3). (Comisia Europeana, Reprezentanta in Romania, 2018; European Institute for Gender Equality, 2017; OECD, 2018) However, the employment rate is only $57.4 \%$ among women (65.3\% of the EU average), while among men it is up to $73.1 \%$ (76.9\% of EU average). The fact that only one of two women is officially employed is strongly influenced by family responsibilities and childcare. The rate of employment of women is correlated with the number of children in preschool education (only $10 \%$ of all children under three years go to kindergarten, which places us on the last places in Europe). (Paul, 2016)

The greatest challenges are in the domains of time and power. The gender division of time dedicated to care activities has become more unequal. Gender equality in decision-making is below the EU average. The representation of women on corporate boards of publicly listed companies has decreased. In 2005, $14 \%$ of members were women, compared to $11 \%$ in 2015. (European Institute for Gender Equality, 2017b)

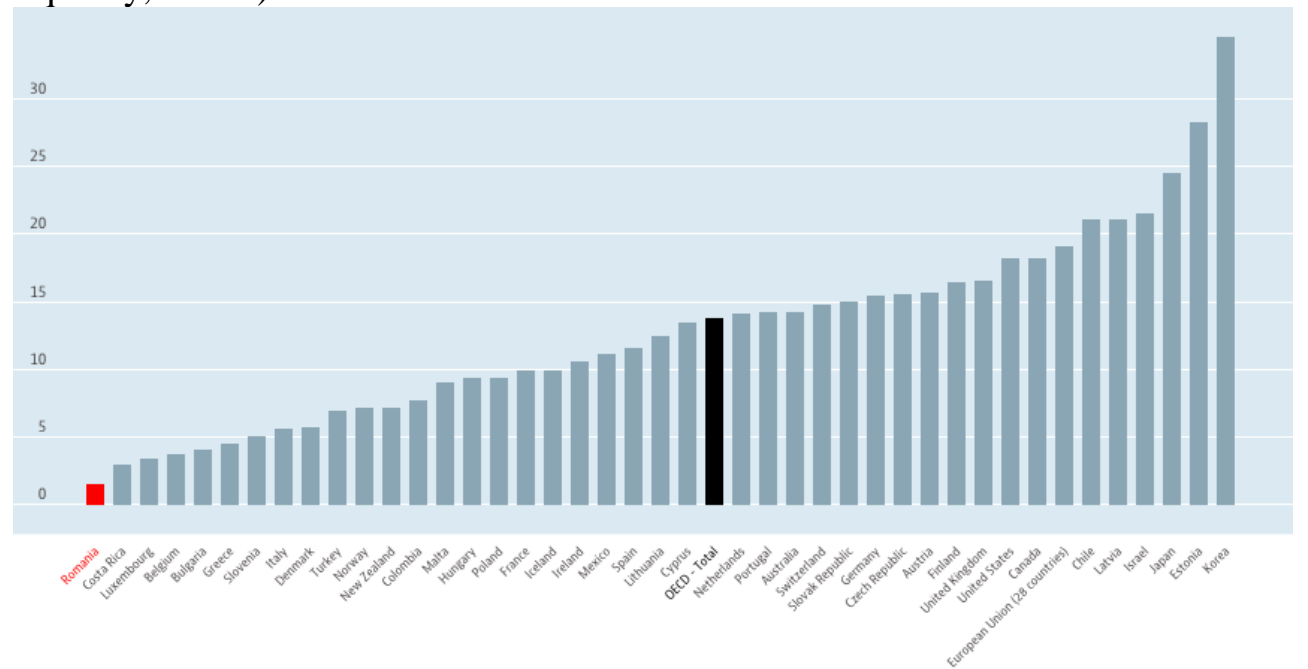

Figure 3. Gender wage gap, Employees, Percentage points, Annual, 2014 - 2017 (Source: OECD, 2018)

\section{Underlying causes}

What explains these gender gaps? What are the underlying causes? The literature offers a myriad of explanations.

The problem arises when young adults try to balance work and family, and women end up carrying nearly all caring responsibilities. Women are more likely to spend time caring for their family. $46 \%$ of women have daily care responsibilities for one hour or more, compared to $25 \%$ of men. This gap has 
widened and is greater among couples with children (82\% of women and 52\% of men) than among couples without children (19\% of women and $12 \%$ of men). Among women and men aged $25-49,62 \%$ of women and $37 \%$ of men have daily care responsibilities. (European Institute for Gender Equality, 2017)

In recent research, Schuller (2018) tries to explain how women are still lagging behind men although women's 'human capital' is now significantly greater than men's. First, there is straightforward discrimination: women are denied jobs or paid less because of their sex. Secondly, there are structural reasons, most notably the absence of (or expensive) childcare. The third factor is psychology: women often lack the self-confidence to put themselves forward for a job, even when they are very well qualified for it. And they are often poor negotiators (Babcock \& Laschever, 2003; Blau \& Kahn, 2003) Men, by contrast, are readier to apply even when they lack the official requirements. Fourth, women lack the vertical network connections: they know fewer people in higher level jobs who can help them with mentoring and information. (Hewlett, 2002) The fifth factor is about choice: Women may make the positive choice not to rise as high as they might. They may opt for a better quality of life, including working life, by not subjecting themselves to the strains and stresses of working full-time. They may prefer to look for jobs in sectors that provide the satisfaction of working with people. They may prefer a lateral to a vertical career. (Croson \& Uri, 2009; Schuller, 2018)

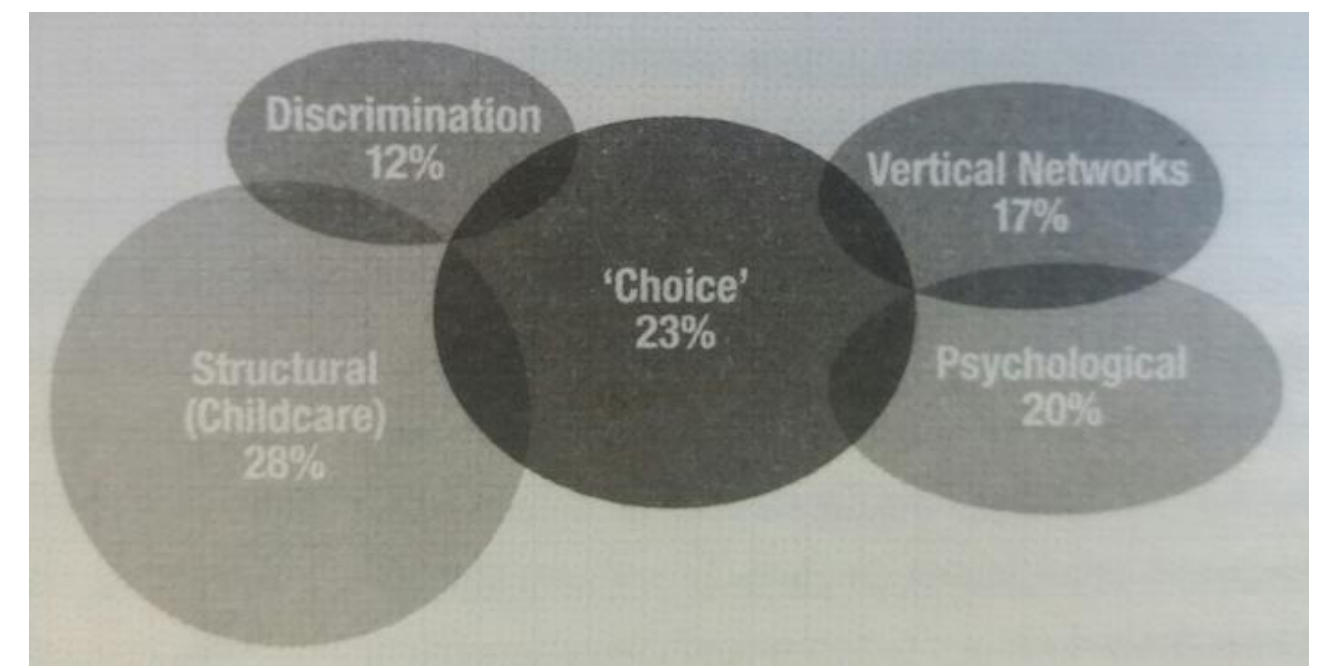

Figure 4. Factors That Explain the Gender Gap in the Economy. Survey 2012-2016 (Schuller, 2018: 77) 


\section{Perspectives}

Research reveals that inequality may have long-term costs in terms of its effects on society-wide well-being and economic growth. (Woetzel, 2015; Seguino, 2016) How can the gender gap be further closed so that future generations of girls and young women don't have to wait that long to get paid fairly?

First, in order to close the gender gap in economic participation and opportunity, it is important to find the reasons that generated this gap. While explanations such as the glass ceiling (an intangible barrier within a hierarchy that prevents women from obtaining upper-level positions) and glass cliff (a metaphor that refers to the tendency of groups, organisations or political parties to put women in power during times of crisis or downturn, when the likelihood of failure is highest) have been put forward, self-selection, that is, differences in leadership ambition, is likely a major factor behind these gender gaps. Understanding the forces behind self-selection into leadership positions is an important step toward designing effective policies that can mitigate inefficient gender gaps in labour markets as well as in corporate or political decision-making. (HCEO, 2017)

Society should invest in "economic leadership". Universities, NGO's and companies ought to implement leadership training programmes targeted at females, designed to both build women's leadership skills (e.g. responsibility of making decisions on behalf of others in risky contexts) and get them interested in leadership in the first place.

The advancement of women to leadership roles in management, and also boards of publicly traded companies, are crucial. A regulation that would require publicly traded companies to disclose what the gender composition of their board is, would be a good step in the right direction.

Romania is also behind when it comes to female entrepreneurs that start new companies. Only one-third of our entrepreneurs are women, although a significant number of them are successful. There have been some initial initiatives to stimulate women entrepreneurship. But these programmes have been rather scarce and had low outputs and were not integrated in a coherent and realistic vision. One of the major factors that inhibits female entrepreneurship spirit are bureaucratic barriers and the difficult access to needed start-up resources. It is a proven fact that women have less access to start-up capital: financial capital; human capital - such as professional or managerial expertise or training; and social capital - that is, access to professional networks. This affects the size of start-ups, as well as the choice of the business domain. The result is that women-run businesses are merely concerned with survival, with a limited vision.

One of the biggest challenges for women will be robotics and automation. The World Economic Forum predicts that robots will replace women at twice the rate of men. That should be a concern for women who may be impacted by automation. Women need to start now to retrain and get the skills they need to stay relevant in the workforce of the future. (King, 2018) Paradoxically, there is evidence that a competence gap is growing fast between women and men, as girls

512 Review of International Comparative Management

Volume 19, Issue 5, December 2018 
not only outperform boys academically, but women generally are keener to take part in adult education and participate more than men in workplace training. "That competence gap is increasing faster than the gap between the pay and career patterns of men and women is closing. (Schuller, 2017: x) More research needs to be done on what hold girls and women back to become entrepreneurs or stockbrokers.

In terms of policies, the public and private sectors, governments and businesses could jointly try to ensure the following in order to close the gender participation, remuneration and advancement gaps:

- provide affordable, good-quality childcare for all parents and paid maternity leave for mothers in employment; encourage more equal sharing of parental leave by, for example, reserving part of paid leave entitlements for the exclusive use of fathers;

- remove disincentives to paid work created by taxes and benefit systems and ensure that work pays for both parents;

- address cultural barriers and the stereotyping of women's roles in society, business and the public sector;

- introduce targets and measures to monitor progress on female representation on the boards of listed companies;

- ensure that policies for female-owned enterprises target not only startups and small enterprises, but encourage and support the growth ambitions of all existing firms;

- promote comprehensive support programmes that target female-owned enterprises in high-tech sectors;

- ensure equal access to finance for male and female entrepreneurs. (OECD, 2012)

\section{References}

Babcock, L. \& Laschever, S., 2003. Women Don't Ask: Negotiation and the Gender Divide. New York: Bantam Books.

Blau, F. \& Kahn, L., 2003. "Understanding the International Differences in the Gender Pay Gap," Journal of Labor economics 21: 106-144.

Bohnet, I., 2016. What Works. Gender Equality by Design. Cambridge: Harvard University Press.

Brooke-Marciniak, B., 2018. From glass ceiling to glass cliff: women are not a leadership quick-fix, World Economic Forum, https://www.weforum.org /agenda/2018/12/glass-ceiling-cliff-women-leadership-fix/

Bunch, C., 2012. "Opening Doors for Feminism: UN World Conferences on Women," Journal of Women's History 24(4): 213-221.

Cerise, S., Francavilla, F., 2012. Tackling the root causes of gender inequality. Paris: OECD Development Centre, https://www.researchgate.net/ publication/271826265_Tackling_the_root_causes_of_gender_inequality 
Comisia Europeana, Reprezentanta in Romania, 2018, https://ec.europa.eu/ romania/news/20180308_raport_egalitate_de_sanse_femei_barbati_romani a_ro

Croson, R. \& Uri, G., 2009. "Gender Differences in Preferences," Journal of Economic Literature 47(2): 448-74.

England, P., Farkas, G., Kilbourne, B., Dou, T., 1988. "Explaining Occupational Sex Segregation and Wages: Findings From a Model of Fixed Effects," American Sociological Review 53: 544-559.

European Institute for Gender Equality, 2017. Gender Equality Index 2017. Measuring gender equality in the European Union 2005-2015. Report. DOI: 10.2839/251500, https://eige.europa.eu/sites/default/files/documents /20177277_mh0517208enn_pdf.pdf

European Institute for Gender Equality, 2017b. Gender Equality Index 2017: Romania, https://eige.europa.eu/rdc/eige-publications/gender-equalityindex-2017-romania

Fraser, A.S., 1999. "Becoming human: The origins and development of woman's human rights," Human Rights Quarterly 21(4): 853-906.

Hausmann, R., Tyson, L.D., Zahidi, S., 2006. The Global Gender Gap Report 2006. Geneva: World Economic Forum.

HCEO, 2017. Research Spotlight: Understanding Gender Differences in Leadership, https://hceconomics.uchicago.edu/news/research-spotlightunderstanding-gender-differences-leadership

Institutul National de Statistica (INS), 2018. http://statistici.insse.ro:8077/tempoonline/\#/pages/tables/insse-table

King, M., 2018. Forbes, 7 March, http://www.forbes.com/sites/michelleking /2018/03/07/tackling-the-number-one-cause-of-gender-inequality-at-workunequal-pay/\#6860d075f092

Hewlett, S.A., 2002. "Executive Women and the Myth of Having It All," Harvard Business Review, April, https://hbr.org/2002/04/executive-women-and-themyth-of-having-it-all

Lopez-Claros, A. \& Zahidi, S., 2005. Women's Empowerment: Measuring the Global Gender Gap. Geneva: World Economic Forum.

Magnusson, C., 2010. Mind the Gap: Essays on Explanations of Gender Wage Inequality. Stockholm: Swedish Institute for Social Research.

Marçal, K., 2015. Who Cooked Adam Smith's Dinner. A story about women and economics. London: Portobello Books.

Noland, M., Moran, T., Kotschwar, B., 2016. Is Gender Diversity Profitable? Evidence from a Global Survey. Working Paper Series. Washington, DC: Peterson Institute for International Economics, https://piie.com/ publications/wp/wp16-3.pdf

OECD, 2018. Gender wage gap (indicator). doi: 10.1787/7cee77aa-en, http://www.oecd.org/gender/data/genderwagegap.htm [accessed on 23 December 2018]

514 Review of International Comparative Management Volume 19, Issue 5, December 2018 
OECD, 2012. Closing the Gender Gap: Act Now. Paris: OECD Publishing, http://www.oecd.org/gender/closingthegap.htm

Paul, A., 2016. Forţa economică a femeilor. Bucharest: Editura Polirom.

Schuller, T., 2018. The Paula Principle. Why women lose out at work - and what needs to be done about it. Melbourne/London: Scribe.

Seguino, S., 2016. Global Trends in Gender Equality, Journal of African Development 18:1-30, http://www.jadafea.com/wp-content/uploads/2016/ 04/02_Seguino_rev1.pdf

Tomasevski, K., 2002. "Rights of Women: From Prohibition to Elimination of Discrimination," International Social Science Journal 158: 545-558.

Tudorache, O., 2011. Inegalitatea de gen in Romania, http://www.academia.edu/4223964/Inegalitatea_de_gen_\%C3\%AEn_Rom $\%$ C3\%A2nia

UN-INSTRAW, 2011. Glossary of Gender-Related Terms and Concepts.

United Nations, 1995. Beijing Declaration and Platform for Action, Fourth World Conference on Women.

Vaileanu, C., Rusu, V., Cantarji, V., 2008. Ghidul utilizatorului statisticilor de gen. Chișinău: UNIFEM and UNDP, Editia I-a, http://www2.un.md/UNIFEM/programme_areas/statistics/women_men/Ge nder_Statistics_User_Guide_Ro.pdf

Woetzel, J. et al, 2015. The power of parity: How advancing women's equality can add \$12 trillion to global growth. Shanghai: McKinsey Global Institute.

Wirth, L., 2004. Breaking through the Glass Ceiling: Women in Management. Geneva: International Labour Organization.

World Economic Forum, 2018. The Global Gender Gap Report 2018. Cologny/Geneva: World Economic Forum. 